\title{
Physico-chemical Parameters and Antioxidant Activity of Romanian Sea Buckthorn Berries
}

\author{
VIOLETA ALEXANDRA ION ${ }^{1}$, OANA CRISTINA PARVULESCU ${ }^{2 *}$, DIANA VELCEA ${ }^{3}$, OANA POPA ${ }^{3}$, \\ MIRELA AHMADI ${ }^{4}$ \\ ${ }^{1}$ Research Center for Studies of Food and Agricultural Products Quality, University of Agronomic Sciences and \\ Veterinary Medicine Bucharest, 59 Marasti Blvd., 011464, Bucharest, Romania \\ ${ }^{2}$ University Politehnica of Bucharest, Chemical and Biochemical Engineering Department, 1-3 Gheorghe Polizu, \\ 011061, Bucharest, Romania \\ ${ }^{3}$ SCIENT Research Center for Instrumental Analysis, 1 Petre Ispirescu Str., 077167, Tancabesti, Ilfov, Romania \\ ${ }^{4}$ Banat's University of Agriculture Science and Veterinary Medicine "King Michael I of Romania" from Timisoara, \\ Biochemistry and Molecular Biology Department, 119 Calea Aradului, 300645, Timisoara, Romania
}

\begin{abstract}
Physico-chemical parameters of Romanian sea buckthorn fresh or dried berries, including titratable acidity $(2.28 \pm 0.06 \mathrm{~g}$ malic acid/100 g FM), $\mathrm{pH}(2.60 \pm 0.08)$, contents of moisture $(75.94 \pm 2.14 \mathrm{~g} / 100 \mathrm{~g} F M)$, ash $(2.83 \pm 0.11 \mathrm{~g} / 100 \mathrm{~g} \mathrm{DM})$, ascorbic acid $(1337.6 \pm 37.2 \mathrm{mg} / 100 \mathrm{~g}$ FM), oil (3.82 $\pm 0.16 \mathrm{~g} / 100 \mathrm{~g} \mathrm{FM})$, and macro elements, mainly $\mathrm{K}(11654 \mathrm{mg} / \mathrm{kg} \mathrm{DM}), \mathrm{Mg}(668$ $\mathrm{mg} / \mathrm{kg} \mathrm{DM}), C a(645 \mathrm{mg} / \mathrm{kg} \mathrm{DM}), \mathrm{Na}(401 \mathrm{mg} / \mathrm{kg} \mathrm{DM})$, and $P(271 \mathrm{mg} / \mathrm{kg} \mathrm{DM})$, were evaluated in this paper. The most abundant volatile compounds found in the volatile fraction of berries were isopentyl isovalerate (30.8\%), heptanal (11.7\%), ethyl hexanoate (10.5\%), ethyl isovalerate (8.1\%), hexanal (7.5\%), and ethyl 2-methylbutyrate (6.3\%). Total phenolic content, total flavonoids content, and antioxidant activity (expressed as DPPH free radical scavenging activity by inhibition of DPPH) of extract solutions obtained from dried berries by MAE using ethanol/water mixture as a solvent were estimated at different ratios of solvent volume/vegetal material mass $(15-30 \mathrm{~mL} / \mathrm{g})$ and ethanol/water $(50 / 50,60 / 40,70 / 30$, and $80 / 20 \mathrm{v} / \mathrm{v})$. Inhibition of DPPH (22.61-48.60\%) was well correlated with total phenolic content (4.42-10.04 mg caffeic acid equivalents/g DM) and total flavonoids content (5.37-11.14 mg quercetin equivalents/g DM).
\end{abstract}

Keywords: Sea buckthorn, ascorbic acid, titratable acidity, oil, volatiles, minerals, total phenols, total flavonoids, antioxidant activity

Hippophae rhamnoides L., commonly known as sea buckthorn (SB), is a plant widely studied for its nutritional and therapeutic benefits. H. rhamnoides species comprises nine subspecies which grow especially in temperate Europe and Asia, i.e., carpatica, fluviatilis, and rhamnoides in Europe, caucasia, mongolica, sinensis, turkestanica, wolongensis, and yunnanensis in Asia [1].

Although all parts of this plant (berry, leaf, root, twig, bark) are sources of bioactive compounds, the berry, containing cca. 200 components, is considered the most important part [2]. SB berries are rich in natural antioxidants, e.g., phenolic compounds (including flavonoids, phenolic acids, tocopherols), carotenoids (such as $\beta$-carotene, $\gamma$ carotene, lycopene, zeaxanthin, lutein), ascorbic acid (vitamin C), which exhibit anti-inflammatory, anticancer, and antimicrobial effects [2-18]. Moreover, the berries are important sources of sugars (mainly glucose and fructose), proteins, organic acids (predominantly malic acid), aminoacids, essential fatty acids (FAs), volatile compounds, phytosterols (mainly $\beta$-sitosterol), and mineral elements (especially $\mathrm{K}, \mathrm{Mg}, \mathrm{Ca}$, $\mathrm{Na}$, and $\mathrm{P}$ ) [2-10,12-15,17-19]. The composition of SB berries varies depending on the subspecies, origin, climate, and harvest time.

The berries are usually pressed, resulting in juice and a pomace (containing seeds and a fraction of peel and pulp (PP)) SB juice is rich in flavonoids, carotenoids, sugars, organic acids, aminoacids, essential FAs, volatile compounds, phytosterols, vitamins, and minerals $[4,5,13,18]$. Oils extracted from berries, seeds, and PP fraction contain high amounts of unsaturated FAs, carotenoids, tocopherols, and phytosterols and can be used as ingredients in functional food, nutritional supplements, pharmaceutical and cosmetic products [2,3,9,10,13-15,20]. Oils from berries and seeds can be used for treatment of burns, wounds, gastrointestinal disorders, obesity, skin and liver diseases [2,3,10,13-15]. SB juice and oils have beneficial effects on the blood cholesterol level and cardiovascular system $[2,9,10,13,15]$. Antimutagenic, immunomodulatory, hepatoprotective, neuroprotective, radioprotective, anti-stress, and anti-aging effects of SB berries and related products were also reported [2,3,7,9,10,12-15,19].

This paper has aimed at evaluating the quality of Romanian SB. Contents of moisture, ash, ascorbic acid, oil, volatile compounds, and minerals as well as titratable acidity and $\mathrm{pH}$ of berries were determined by specific methods. Moreover, total phenolic content, total flavonoids content, and antioxidant activity of berry extracts were evaluated.

*email:oana.parvulescu@yahoo.com 


\section{Experimental part \\ Materials}

SB wild berries (Hippophae rhamnoides L. ssp. carpatica) were collected in September 2017 in Prahova region of Romania. The fresh berries were manually cleaned to remove leaves, branches, and berries damaged by harvesting and then wind flow screened. Cleaned berries were dosed in samples of $0.5 \mathrm{~kg}$ and stored in a freezer at $-20{ }^{\circ} \mathrm{C}$ until their analysis. Three replications of each analysis were conducted.

All reagents were purchased from Merck (Germany) and PerkinElmer (USA) and were analytical grade.

\section{Methods \\ Determination of moisture content}

Moisture content (wt\% on a fresh matter (FM) basis) was measured using a Memmert Universal Oven UF 55. SB berries were dried at $60{ }^{\circ} \mathrm{C}$ for $50 \mathrm{~h}$, until a constant mass was achieved.

\section{Determination of ash content}

Ash content (wt\% on a dried matter (DM) basis) was determined using a Carbolite ELF Chamber Furnance. $25 \mathrm{~g}$ of SB dried sample was placed in a crucible and calcined at $550{ }^{\circ} \mathrm{C}$, in $50{ }^{\circ} \mathrm{C}$ steps, until a clean white residue was obtained.

\section{Determination of ascorbic acid content}

Ascorbic acid content (mg/100 g FM) was measured by the iodometric method in the presence of starch as indicator. An amount of $10 \mathrm{~g}$ of fresh fruit sample was crushed and homogenized in a mortar with $2 \mathrm{~g}$ of quartz sand (prewashed with $2 \% \mathrm{HCl}$ solution). Crushed fruits were added in $50 \mathrm{~mL}$ centrifuge tube and filed with $2 \% \mathrm{HCl}$ solution, then centrifuged for $5 \mathrm{~min}$ at $5000 \mathrm{rpm} .10 \mathrm{~mL}$ of the fruit extract supernatant was transferred in an Erlenmeyer glass and $30 \mathrm{~mL}$ of ultrapure water, $5 \mathrm{~mL}$ of $2 \% \mathrm{KI}$ solution, $5 \mathrm{~mL}$ of $37 \% \mathrm{HCl}$, and $1.5 \mathrm{~mL}$ of $2 \%$ starch solution were added. The mixture was titrated with a $0.002 \mathrm{M}$ potassium iodate $\left(\mathrm{KIO}_{3}\right)$ solution.

\section{Determination of oil content}

Oil content (g/100 g FM) was determined by extraction with petroleum ether as solvent in a Soxhlet extractor. Prior to extraction, dried fruits were ground for $20 \mathrm{~s}$ in a laboratory mill (Merck IKA A11 basic). During petroleum ether extraction, the oil temperature was maintained at $80 \pm 1^{\circ} \mathrm{C}$.

\section{Determination of titratable acidity and $p \mathrm{H}$}

$10 \mathrm{~g}$ of fresh fruit was crushed and diluted with $10 \mathrm{~mL}$ ultrapure water. The mixture was homogenized, centrifuged, and the clear liquid was taken for analysis. Titratable acidity (g malic acid (MA)/100 g FM) was determined by titration with $0.1 \mathrm{~N} \mathrm{NaOH}$ using phenolphthalein as indicator. $\mathrm{pH}$ was measured using a Mettler Toledo SevenExcellence $\mathrm{pH}$-meter.

\section{Determination of volatile compounds}

Volatile compounds were determined by GC-MS analysis using a PerkinElmer Clarus 680 Gas Chromatograph (GC) coupled with a Clarus SQ $8 \mathrm{~T}$ Mass Spectrometer (MS) and a TurboMatrix 40 headspace (HS) accessory. Helium $\left(1 \mathrm{~mL} / \mathrm{min}\right.$ flow rate, 20:1 split ratio) was used as a carrier gas. Initial temperature of $\mathrm{GC}$ column was $40{ }^{\circ} \mathrm{C}$ and then increased to $100{ }^{\circ} \mathrm{C}$ at a rate of $1{ }^{\circ} \mathrm{C} / \mathrm{min}$. Temperatures of the ion source (positive) and interface were $150{ }^{\circ} \mathrm{C}$ and $250^{\circ} \mathrm{C}$, respectively. $10 \mathrm{~g}$ of sample was crushed and put in a $20 \mathrm{~mL}$ clear HS vial. The vial containing sample was placed in the HS accessory and heated at $100^{\circ} \mathrm{C}$ for 30 min under stirring.

\section{Determination of minerals}

Mineral analysis was conducted by atomic absorption spectrometry (AAS). $1 \mathrm{~g}$ of fresh fruit was added in a mineralization tube with $8 \mathrm{~mL}$ of ultrapure grade nitric acid and $2 \mathrm{~mL}$ of concentrated hydrochloric acid. A microwave oven (Anton Paar Microwave Reaction System Multiwave PRO) was used for samples mineralization using a power rap of $800 \mathrm{~W}$ for $15 \mathrm{~min}$ and hold for $30 \mathrm{~min}$ at $1100 \mathrm{~W}$. The maximum temperature reached in the vessels was 191.7 ${ }^{\circ} \mathrm{C}$. The mineralized samples were transferred in a $50 \mathrm{~mL}$ flask and completed with ultrapure water. 22 metals were analyzed by a quantitative method using a PerkinElmer ICP-OES Optima 8300DV apparatus (Al, B, Ca, Cu, Fe, Mg, $\mathrm{Mn}, \mathrm{Na}, \mathrm{Ni}, \mathrm{Zn}, \mathrm{K}$ ) and a semiquantitative method in a Perkin Elmer ICP-MS NexION 300S apparatus (Br, $\mathrm{Sr}, \mathrm{Cd}$, $\mathrm{Ba}, \mathrm{Ce}, \mathrm{Pb}, \mathrm{Ti}, \mathrm{P}, \mathrm{V}, \mathrm{Co}, \mathrm{As})$.

\section{Microwave assisted extraction (MAE) of antioxidants}

Application of microwaves generally leads to enhanced antioxidant extraction yields compared to classical extraction [21-24]. MAE of antioxidants from ground dried SB berries using ethanol/water mixture as a solvent was 
performed in an Anton Paar Multiwave PRO Microwave Reaction System equipped with a time controller, an integrated forced-air cooling system, power and temperature sensors. Extraction tests were performed at $60{ }^{\circ} \mathrm{C}$ and different values of SB mass/solvent volume $(1 / 15,1 / 20,1 / 25$, and 1/30 g/mL) and ethanol/water $(50 / 50,60 / 40,70 / 30$, $80 / 20$ and $\mathrm{v} / \mathrm{v}$ ) ratios. Extract solutions obtained by MAE were further used for evaluating the active species content and antioxidant activity.

\section{Determination of total phenolic content}

Total phenolic content of SB extract solutions was evaluated based on Folin-Ciocalteu method [25-27]. $0.5 \mathrm{~mL}$ of extract was mixed with $0.5 \mathrm{~mL}$ of Folin-Ciocalteu reagent and $5 \mathrm{~mL}$ of $20 \%$ sodium carbonate $\left(\mathrm{Na}_{2} \mathrm{CO}_{3}\right)$. The mixture was stirred for $10 \mathrm{~min}$ at room temperature in the dark and further filtered on a $0.45 \mu \mathrm{m}$ filter. The absorbance was measured at $750 \mathrm{~nm}$ using a PerkinElmer LAMBDA $650 \mathrm{UV} /$ Vis Spectrophotometer. A standard curve for caffeic acid (in the range $0.005-0.080 \mathrm{mg} / \mathrm{mL}$ ) was used to determine total phenolic content (mg caffeic acid equivalents (CAE)/g DM).

Determination of total flavonoids content

Total flavonoids content of SB extract solutions was determined using a PerkinElmer LAMBDA 650 UV/Vis Spectrophotometer [25-27]. $0.250 \mathrm{~mL}$ of sample was added to $0.075 \mathrm{~mL}$ of $5 \%$ sodium nitrite $\left(\mathrm{NaNO}_{2}\right)$ solution, the mixture was stirred for $5 \mathrm{~min}$, and then $0.150 \mathrm{~mL}$ of $5.5 \%$ aluminum chloride $\left(\mathrm{AlCl}_{3}\right)$ solution was added. After $6 \mathrm{~min}$, $0.5 \mathrm{~mL}$ of $1 \mathrm{M}$ sodium hydroxide $(\mathrm{NaOH})$ solution was added, the volume was adjusted to $2.5 \mathrm{~mL}$ with distilled water, and the absorbance was measured at $510 \mathrm{~nm}$. A standard curve for quercetin (in the range $0.050-0.300 \mathrm{mg} / \mathrm{mL}$ ) was used to evaluate total flavonoids content (mg quercetin equivalents $(\mathrm{QE}) / \mathrm{g} \mathrm{DM})$.

\section{Determination of antioxidant activity}

Antioxidant activity was evaluated by DPPH (2,2-diphenyl-1-picrylhydrazyl) free radical method [25-27]. $0.1 \mathrm{~mL}$ of quercetin standard solution of different concentrations $(0.010-0.200 \mathrm{mg} / \mathrm{mL})$ was mixed with $3.9 \mathrm{~mL}$ of DPPH solution in methanol $(0.035 \mathrm{mg} / \mathrm{mL})$. The mixture was incubated for $40 \mathrm{~min}$ at room temperature in the dark and its absorbance was measured at $515 \mathrm{~nm}$ using methanol as blank. $0.100 \mathrm{~mL}$ of ethanol prepared similarly with the real sample was used as control sample. In order to perform the extract analysis, the same operations were conducted, with the exception that SB extract was used instead of standard solution. Inhibition of DPPH radical, $I(\%)$, was estimated by Eq. (1), where $A_{c}$ is the absorbance of the control sample and $A_{s}$ the absorbance of the test sample.

$$
I=\left(1-\frac{A_{s}}{A_{c}}\right) \times 100
$$

\section{Results and discussions}

Moisture, ash, ascorbic acid, and oil contents, titratable acidity, and $\mathrm{pH}$

Physicochemical characteristics of SB berries in terms of moisture content (MC), ash content (AC), ascorbic acid content (AAC), oil content (OC), titratable acidity (TA), and $p \mathrm{H}$ are summarized in Table 1. Tabulated data highlight that the results obtained in this study are in the ranges reported in the related literature $[2,3,9-11,13,15,16,18]$. SB berries are known for their high content of vitamin C (up to $2500 \mathrm{mg} / 100 \mathrm{~g} \mathrm{FM}$ ), an natural antioxidant which is a scavenger of free radicals, protects the immune system, diminishes the severity of allergies, and has an essential role in bone formation, wound healing, and various metabolic functions [12,28].

Table 1

MOISTURE CONTENT (MC), ASH CONTENT (AC), ASCORBIC ACID CONTENT (AAC), OIL CONTENT (OC), TITRATABLE ACIDITY (TA), AND $p$ H OF SB BERRIES

\begin{tabular}{|l|l|}
\hline Parameter & Value \\
\hline MC $(\%)$ & $75.94 \pm 2.14$ \\
\hline AC $(\%)$ & $2.83 \pm 0.11$ \\
\hline AAC $(\mathrm{mg} / 100$ g FM $)$ & $1337.6 \pm 37.2$ \\
\hline OC $(\mathrm{g} / 100$ g FM $)$ & $3.82 \pm 0.16$ \\
\hline TA $(\mathrm{g} \mathrm{MA} / 100 \mathrm{~g} \mathrm{FM})$ & $2.28 \pm 0.06$ \\
\hline $\mathrm{pH}$ & $2.60 \pm 0.08$ \\
\hline
\end{tabular}

\section{Volatile compounds}

14 volatile compounds, including 5 aldehydes, 8 esters, and 1 alcohol (Table 2), were identified by GC-MS analysis of volatile fraction of SB berries. The most abundant compounds are as follows: isopentyl isovalerate $(30.8 \%)$, heptanal $(11.7 \%)$, ethyl hexanoate $(10.5 \%)$, ethyl isovalerate $(8.1 \%)$, hexanal $(7.5 \%)$, and ethyl 2methylbutyrate $(6.3 \%)$. These results are in line with those found by other researchers $[2,13]$. 
Table 2

VOLATILE COMPOUNDS IDENTIFIED IN SB BERRIES

\begin{tabular}{|c|c|c|c|}
\hline No. & Class & Compound & Percentage $(\%)$ \\
\hline 1 & alcohols & 3-methyl-2-buten-1-ol & $3.8 \pm 0.12$ \\
\hline 2 & \multirow{5}{*}{ aldehydes } & pentanal & $2.1 \pm 0.08$ \\
\hline 3 & & hexanal & $7.5 \pm 0.25$ \\
\hline 4 & & heptanal & $11.7 \pm 0.48$ \\
\hline 5 & & octanal & $4.0 \pm 0.16$ \\
\hline 6 & & nonanal & $5.1 \pm 0.21$ \\
\hline 7 & \multirow{8}{*}{ esters } & ethyl butyrate & $4.0 \pm 0.14$ \\
\hline 8 & & ethyl 2-methylbutyrate & $6.3 \pm 0.12$ \\
\hline 9 & & ethyl isovalerate & $8.1 \pm 0.31$ \\
\hline 10 & & ethyl hexanoate & $10.5 \pm 0.43$ \\
\hline 11 & & isoamyl acetate & $1.5 \pm 0.06$ \\
\hline 12 & & isopentyl isovalerate & $30.8 \pm 1.15$ \\
\hline 13 & & amyl isovalerate & $1.9 \pm 0.07$ \\
\hline 14 & & 3-methylbutyl octanoate & $2.5 \pm 0.09$ \\
\hline
\end{tabular}

\section{Mineral elements}

Mineral concentrations summarized in Table 3 highlight high contents of essential elements such as K (11654 $\mathrm{mg} / \mathrm{kg} \mathrm{DM}), \mathrm{Mg}(668 \mathrm{mg} / \mathrm{kg} \mathrm{DM}), \mathrm{Ca}(645 \mathrm{mg} / \mathrm{kg} \mathrm{DM}), \mathrm{Na}(401 \mathrm{mg} / \mathrm{kg} \mathrm{DM})$, and P (271 mg/kg DM), while the content of $\mathrm{Cd}, \mathrm{Pb}$, and $\mathrm{As}$, which are potentially toxicological elements, was very low $(\leq 0.7 \mathrm{mg} / \mathrm{kg} \mathrm{DM})$. These values are in line with those reported in the literature $[2,18]$.

Table 3

MINERALS IDENTIFIED IN SB BERRIES

\begin{tabular}{|l|l|l|}
\hline No. & Mineral & Concentration $(\mathrm{mg} / \mathrm{kg}$ DM $)$ \\
\hline 1 & $\mathrm{Al}$ & $47.2 \pm 1.63$ \\
\hline 2 & $\mathrm{~B}$ & $14.5 \pm 0.41$ \\
\hline 3 & $\mathrm{Ca}$ & $644.6 \pm 21.4$ \\
\hline 4 & $\mathrm{Cu}$ & $6.9 \pm 0.08$ \\
\hline 5 & $\mathrm{Fe}$ & $37.5 \pm 1.57$ \\
\hline 6 & $\mathrm{Mg}$ & $667.8 \pm 21.6$ \\
\hline 7 & $\mathrm{Mn}$ & $9.0 \pm 0.14$ \\
\hline 8 & $\mathrm{Na}$ & $401.0 \pm 11.2$ \\
\hline 9 & $\mathrm{Ni}$ & $5.1 \pm 0.11$ \\
\hline 10 & $\mathrm{Zn}$ & $21.5 \pm 0.81$ \\
\hline 11 & $\mathrm{~K}$ & $11654 \pm 417.5$ \\
\hline 12 & $\mathrm{Br}$ & $10.5 \pm 0.41$ \\
\hline 13 & $\mathrm{Sr}$ & $4.9 \pm 0.08$ \\
\hline 14 & $\mathrm{Cd}$ & $0.1 \pm 0.01$ \\
\hline 15 & $\mathrm{Ba}$ & $2.7 \pm 0.04$ \\
\hline 16 & $\mathrm{Ce}$ & $0.1 \pm 0.01$ \\
\hline 17 & $\mathrm{~Pb}$ & $<0.05$ \\
\hline 18 & $\mathrm{Ti}$ & $6.2 \pm 0.12$ \\
\hline 19 & $\mathrm{P}$ & $270.7 \pm 11.3$ \\
\hline 20 & $\mathrm{~V}$ & $0.3 \pm 0.01$ \\
\hline 21 & $\mathrm{Co}$ & $<0.05$ \\
\hline 22 & $\mathrm{As}$ & $0.7 \pm 0.02$ \\
\hline & & \\
\hline
\end{tabular}

\section{Total phenolic content, total flavonoids content, and antioxidant activity}

Table 4 contains values of total phenolic content $\left(c_{T P}\right)$, total flavonoids content $\left(c_{T F}\right)$, and inhibition of DPPH $(I)$ corresponding to MAE tests conducted at a SB mass/solvent volume ratio of $1 / 20 \mathrm{~g} / \mathrm{mL}$ and 4 values of ethanol/water ratio, i.e., 50/50, 60/40, 70/30, and 80/20 v/v. The best results $\left(c_{T P}=8.01 \mathrm{mg} / \mathrm{g} \mathrm{DM}, c_{T F}=8.44 \mathrm{mg} / \mathrm{g} \mathrm{DM}\right.$, and $I=35.06 \%$ ) were obtained for an ethanol/water ratio of 60/40. Further, 3 MAE experiments were performed at an ethanol/water ratio of $60 / 40$ and various levels of SB mass/solvent volume ratio, i.e., 1/15, 1/25, 1/30 g/mL. Experimental data, which are presented in Table 5, highlight an increase in $c_{T P}, c_{T F}$, and $I$ with an increase in the solvent volume. 
Table 4

TOTAL PHENOLIC CONTENT, TOTAL FLAVONOIDS CONTENT, AND INHIBITION OF DPPH DEPENDING ON ETHANOL/WATER RATIO (SB MASS/SOLVENT VOLUME RATIO: $1 / 20 \mathrm{~g} / \mathrm{mL}$ )

\begin{tabular}{|c|c|c|c|c|c|}
\hline Ethanol/water ratio $(\mathrm{v} / \mathrm{v})$ & $c_{T P}(\mathrm{mg} \mathrm{CAE} / \mathrm{g} \mathrm{DM})$ & $c_{T F}(\mathrm{mg} \mathrm{QE} / \mathrm{g} \mathrm{DM})$ & \multicolumn{2}{|l|}{$I(\%)$} & \multirow{2}{*}{$\begin{array}{l}\varepsilon \\
(\%)\end{array}$} \\
\hline Value & experimental & experimental & experimental & predicted & \\
\hline $50 / 50$ & 6.03 & 6.94 & 29.76 & 29.87 & -0.35 \\
\hline $60 / 40$ & 7.65 & 8.58 & 35.06 & 37.95 & 0.55 \\
\hline $70 / 30$ & 5.82 & 6.77 & 28.82 & 29.19 & -1.27 \\
\hline $80 / 20$ & 4.42 & 5.37 & 22.61 & 22.35 & 1.15 \\
\hline
\end{tabular}

Table 5

TOTAL PHENOLIC CONTENT, TOTAL FLAVONOIDS CONTENT, AND INHIBITION OF DPPH DEPENDING ON SB MASS/SOLVENT VOLUME RATIO (ETHANOL/WATER RATIO: 60/40 v/v)

\begin{tabular}{|c|c|c|c|c|c|}
\hline SB mass/solvent ratio $(\mathrm{g} / \mathrm{mL})$ & $c_{T P}(\mathrm{mg}$ CAE/g DM $)$ & $c_{T F}(\mathrm{mg} \mathrm{QE} / \mathrm{g} \mathrm{DM})$ & \multicolumn{2}{|l|}{$I(\%)$} & \multirow{2}{*}{$\begin{array}{l}\varepsilon \\
(\%)\end{array}$} \\
\hline Value & experimental & experimental & experimental & predicted & \\
\hline $1 / 15$ & 7.13 & 7.74 & 35.51 & 35.51 & 0.01 \\
\hline $1 / 20$ & 7.65 & 8.58 & 38.16 & 38.23 & -0.18 \\
\hline $1 / 25$ & 8.94 & 9.97 & 44.02 & 43.88 & 0.32 \\
\hline $1 / 30$ & 10.04 & 11.14 & 48.60 & 48.67 & -0.15 \\
\hline
\end{tabular}

Experimental data listed in Tables 4 and 5 were processed by multiple regression analysis resulting in Eqs. 2 $\left(R^{2}=0.9979, R_{\text {adjusted }}^{2}=0.9937\right)$ and $3\left(R^{2}=0.9997, R_{\text {adjusted }}^{2}=0.9991\right)$, which correlate $I$ with $c_{T P}$ and $c_{T F}$. Tables 4 and 5 contain also values of $I$ predicted based on Eqs. 2 and 3 as well as those of percent error, $\varepsilon$ (\%), defined by Eq. 4 . Tabulated results $(-1.27 \% \leq \varepsilon \leq 1.15 \%)$ highlight a very good agreement between experimental and predicted data, i.e., $I_{e x}$ and $I_{p r}$.

$$
\begin{gathered}
I=-3.759 c_{T P}+8.642 c_{T F}-7.442 \\
I=2.664 c_{T P}+1.593 c_{T F}+4.181 \\
\varepsilon=\left(1-\frac{I_{p r}}{I_{e x}}\right) \times 100
\end{gathered}
$$

Experimental values of $c_{T P}, c_{T F}$, and $I$, which are specified in Table 5, are plotted in Fig. 1 against solvent volume/SB mass ratio, $R_{v m}(\mathrm{~mL} / \mathrm{g})$. All three parameters are well correlated with $R_{v m}$ by straight lines described by Eqs. (5)-(7), where determination coefficients $\left(R^{2}\right)$ corresponding to them are 0.9747, 0.9916, and 0.9813, respectively.

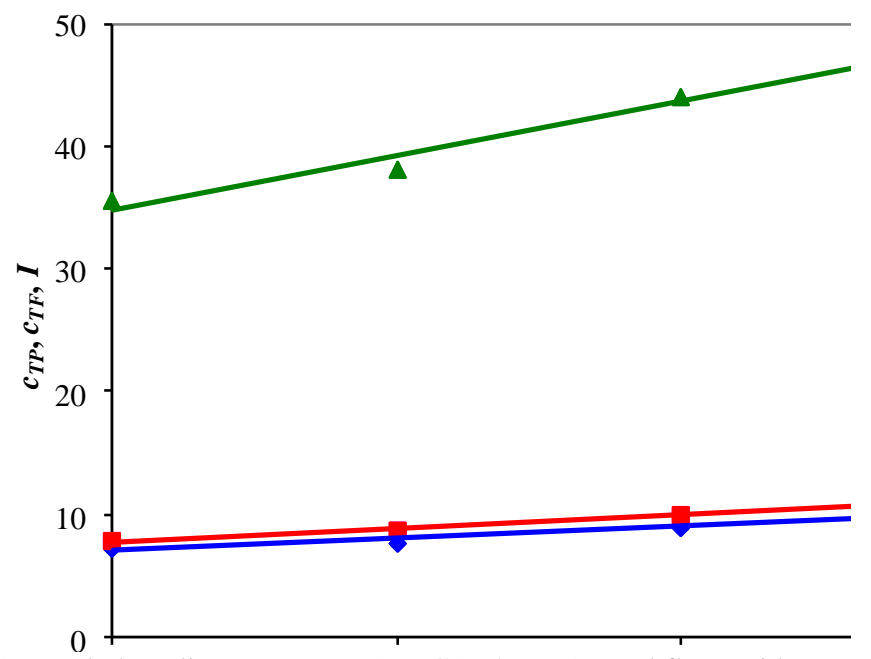

Fig. 1. Total phenolic content, $c_{T P}(\mathrm{mg} \mathrm{CAE} / \mathrm{g} \mathrm{DM})$, total flavonoids content, $c_{T F}(\mathrm{mg} \mathrm{QE} / \mathrm{g} \mathrm{DM})$, and inhibition of DPPH, $I(\%)$ depending on solvent volume $/ \mathrm{SB}$ mass ratio, $R_{v m}(\mathrm{~mL} / \mathrm{g})($ ethanol/water ratio: $60 / 40 \mathrm{v} / \mathrm{v})$ :

$$
\begin{gathered}
\bullet{ }_{T P P} \bullet c_{T F}, \boldsymbol{\Delta} I \\
c_{T P}=0.200 R+3.931 \\
c_{T F}=0.232 R+4.142 \\
I=0.903 R+21.264
\end{gathered}
$$


Substituting Eq. (6) in Eq. (5) results in Eq. (8) $\left(R^{2}=0.9950\right)$ and substituting Eq. (8) in Eq. (3) results in Eqs. (9) and (10) $\left(R^{2}=0.9989\right.$ and $\left.R^{2}=0.9979\right)$, which highlight very good correlations between $c_{T P}$ and $c_{T F}, I$ and $c_{T P}$, and $I$ and $c_{T F}$.

$$
\begin{aligned}
& c_{T P}=0.870 c_{T F}+0.301 \\
& I=4.486 c_{T P}+3.708 \\
& I=3.910 c_{T F}+4.983
\end{aligned}
$$

\section{Conclusions}

Some physico-chemical properties and antioxidant activity of Romanian seabuckthorn (SB) wild berries collected in Prahova region were evaluated. The results of physico-chemical analysis of fresh or dried berries were as follows: $75.94 \pm 2.14 \mathrm{~g}$ moisture/100 g FM, 2.83 $\pm 0.11 \mathrm{~g}$ ash/100 g DM, 1337.6 $\pm 37.2 \mathrm{mg}$ ascorbic acid/100 g FM, 3.82 $\pm 0.16 \mathrm{~g}$ oil/100 g FM, titratable acidity of $2.28 \pm 0.06 \mathrm{~g}$ malic acid/100 g FM, 2.60 $\pm 0.08 \mathrm{pH}, 11654 \mathrm{mg} \mathrm{K} / \mathrm{kg} \mathrm{DM}, 668 \mathrm{mg}$ $\mathrm{Mg} / \mathrm{kg} \mathrm{DM}, 645 \mathrm{mg} \mathrm{Ca} / \mathrm{kg} \mathrm{DM}, 401 \mathrm{mg} \mathrm{Na} / \mathrm{kg} \mathrm{DM}, 271 \mathrm{mg}$ P/kg DM. The most abundant volatile compounds determined by GC-MS analysis of volatile fraction of SB berries were isopentyl isovalerate (30.8\%), heptanal $(11.7 \%)$, ethyl hexanoate $(10.5 \%)$, ethyl isovalerate $(8.1 \%)$, hexanal $(7.5 \%)$, and ethyl 2 -methylbutyrate $(6.3 \%)$. Total phenolic content $\left(c_{T P}\right)$, total flavonoids content $\left(c_{T F}\right)$, and antioxidant activity (expressed as DPPH free radical scavenging activity by inhibition of DPPH $(I)$ ) of extract solutions obtained from dried berries by MAE using ethanol/water mixture as a solvent were estimated at different ratios of solvent volume/SB mass $\left(R_{v m}=15-30 \mathrm{~mL} / \mathrm{g}\right)$ and ethanol/water $(50 / 50,60 / 40,70 / 30$, and $80 / 20 \mathrm{v} / \mathrm{v})$. For an ethanol/water ratio of 60/40 v/v, $c_{T P}(7.13-10.04 \mathrm{mg}$ $\mathrm{CAE} / \mathrm{g} \mathrm{DM}), c_{T F}$ (7.74-11.14 mg QE/g DM), and $I(35.51-48.60 \%)$ increased linearly with $R_{v m}$. Moreover, $I$ was very well correlated with $c_{T P}\left(R^{2}=0.9989\right)$ and $c_{T F}\left(R^{2}=0.9979\right)$.

\section{References}

1. LIAN, Y., CHEN, X., KUN, S., MA, R., Novon, 13, no. 2, 2003, p. 200.

2. BAL, L.M., MEDA, V., NAIK, S.N., SATYA, S., Food Res. Int., 44, no. 7, 2011, p. 1718.

3. BEVERIDGE, T., LI, T.S.C., OOMAH, B.D., SMITH, A., J. Agric. Food Chem., 47, no. 9, 1999 , p. 3480.

4. CIOROI, M., CHIRIAC, E.R., STEFAN, C.S., Rev. Chim. (Bucharest), 68, no. 2, 2017, p. 300.

5. DOBRE, T., PARVUlESCU, O.C., POPESCU, M., STOICA-GUZUN, A., COZEA, A., J. Food Eng., 219, 2018, p. 38.

6. ISOPENCU, G., STROESCU, M., BROSTEANU, A., CHIRA, N., PARVULESCU, O.C., BUSUIOC, C., STOICA-GUZUN, A., J. Food

Process Eng., 42, no. 1, 2019, e12947.

7. KRUCZEK, M., SWIDERSKI, A., MECH-NOWAK, A., KROL, K., Acta Biochim. Pol., 59, no. 1, 2012 , p. 135.

8. MADAWALA, S.R.P., BRUNIUS, C., ADHOLEYA, A., TRIPATHI, S.B., HANHINEVA, K., HAJAZIMI, E., SHI, L., DIMBERG, L.,

LANDBERG, R., J. Food Compos. Anal., 72, 2018, p. 115.

9. OLAS, B., Food Chem. Toxicol., 97, 2016, p. 199.

10. OLAS, B., J. Ethnopharmacol., 213, 2018, p. 183.

11. ROP, O., ERCISLI, S., MLCEK, J., JURIKOVA, T., HOZA, I., Turk. J. Agric. For., 38, no. 2, 2014 , p. 224.

12. STOBDAN, T., CHAURASIA, O.P., KOREKAR, G., MUNDRA, S., ALI, Z., YADAV, A., SINGH, S.B., Defence Sci. J., 60, no. 2, 2010, p. 226.

13. STOBDAN, T., KOREKAR, G., SRIVASTAVA, R.B., Curr. Nutr. Food Sci., 9, no. 2, 2013 , p. 1.

14. SURYAKUMAR, G., GUPTA, A., J. Ethnopharmacol., 138, 2011, p. 268.

15. VESCAN, A., PAMFIL, D., BELE, C., MATEA, C., SISEA, C.R., Not. Bot. Hort. Agrobot. Cluj, 38, no. 2,2010 , p. 114.

16. YILDIZ, H., SENGUL, M., CELIK, F., ERCISLI, S., DURALIJA, B., Agriculture Conspectus Scientificus (ACS), 77, no. 1, 2012 , p. 53.

17. ZEB, A., J. Biol. Sci., 4, no. 5, 2004, p. 687.

18. ZEB, A., Pak. J. Nutr., 3, no. 2, 2004, p. 99.

19. NEGI, P.S., CHAUHAN, A.S., SADIA, G.A., ROHINISHREE, Y.S., RAMTEKE, R.S., Food Chem., 92,2005, p. 119.

20. STOICA-GUZUN, A., PARVULESCU, O.C., BROSTEANU, A., CHIRA, N., STROESCU, M. DOBRE, T., J. Food Nutr. Res.-Slov., 57, no. 4, 2018, p. 363.

21. ASOFIEI, I., CALINESCU, I., GAVRILA, A.I., IGHIGEANU, D., MARTIN, D., Rev. Chim. (Bucharest), 69, no. 8, 2018 , p. 1976.

22. ASOFIEI, I., CALINESCU, I., TRIFAN, A., DAVID, I.G., GAVRILA, A.I., Chem. Eng. Commun., 203, no. 12, 2016 , p. 1547.

23. CALINESCU, I., LAVRIC, V., ASOFIEI, I., GAVRILA, A.I., TRIFAN, A., IGHIGEANU, D., MARTIN, D., Chem. Eng. Process., 122,

2017 , p. 373.

24. GAVRILA, A.I., ASOFIEI, I., CHIPURICI, P., Rev. Chim. (Bucharest), 68, no. 4, 2017 , p. 639.

25. ASANICA, A., MANOLE, C., TUDOR, V., DOBRE, A., TEODORESCU, R.I., AgroLife Scientific Journal, 5, no. 1, 2016, p. 15.

26. FINTINERU, A., MANOLE, C.G., Smedescu, D., Rodino, S., Fintineru, S.C., Butu, A.E., Rom. Biotechnol. Lett., 20, no. 1, 2015 , p. 10036.

27. TUDOR, V., MANOLE, C.G., TEODORESCU, R., ASANICA, A., BARBULESCU, I.D., Agriculture and Agricultural Science Procedia, 6, 2015 , p. 157.

28. IQBAL, K., KHAN, A., KHATTAK, M.M.A.K., Pak. J. Nutr., 3, no. 1, 2004, p. 5.

Manuscript received: 25.04 .2019 
